\title{
GAYA KEPEMIMPINAN DI KANTOR BINA ARTHA CABANG SRENGAT KABUPATEN BLITAR UPAYA MENINGKATKAN MOTIVASI DAN KINERJA KARYAWAN
}

\author{
Novi Catur Muspita \\ Dosen Sospol Universitas Islam Balitar \\ Email: novicatur69@gmail.com
}

\begin{abstract}
ABSTRAK
Dalam kehidupan sehari-hari manusia tidak pernah lepas dari kehidupan berorganisasi, karena pada kodratnya manusia merupakan makhluk sosial yang cenderung untuk selalu hidup bermasyarakat. Salah satunya adalah upaya dalam peningkatan sumber daya manusia dalam perusahaan atau organisasi. Lembaga keuangan syariah, mendasarkan dirinya pada operasional syariah yang diturunkan dalam ekonomi Islam. Hasil Penelitian adalah: (1) Kepemimpinan demokratis merupakan gaya kepemimpinan yang diterapkan di Kantor Bina Artha Cabang Srengat berupaya Berusaha menyelaraskan kepentingan dan tujuan pribadi dengan kepentingan organisasi, (2) Senang menerima saran, pendapat dan kritik dari bawahannya, Mentorelir bawahan yang membuat kesalahan dengan memberikanpendidikan kepada bawahan untuk tidak mengulangi kesalahan , Lebih menitikberatkan kerjasama dalam mencapai tujuan . (3) Selain itu semua terselip sebuah program yaitu koin telat dimulai bulan Juni . Koin telat ini merupakan program , jam masuk kantor itu 08.00 apabila salah satu karyawan telat datang kantor dengan aturan per 30 menit mlaumpaui jam 08.00 akan membayar sebesar Rp.2500, dan utuk kepala cabang sendiri dendanya 2 X lipat dari karyawan . Hal ini digunkana untuk mengingkatkan tingkat kedisiplinan karyawan dan sudah banyak perubahan dari karyawan . saran : Untuk mempertahankan dan meningkatkan kinerja pegawai sesuai kriteria kinerja yang telah diterapkan, selalu melakukan inovasi - inovasi untuk menyesuaikan dengan problem dilapangan juga selain itu factor perkembangan teknologi, Agar gaya kepemimpinan di Kantor Bina Artha Cabang Srengat berdampak positif bagi peningkatan kinerja pegawai, maka kepemimpinan kepala Kantor Bina Artha Cabang Srengat perlu diberdayakan.
\end{abstract}

Kata kunci: Gaya kepemimpinan, Bina Artha, kinerja karyawan 


\section{PENDAHULUAN}

Dalam kehidupan sehari-hari manusia tidak pernah lepas dari kehidupan berorganisasi , karena pada kodratnya manusia merupakan makhluk sosial yang cenderung untuk selalu hidup bermasyarakat. Hal ini nampak baik didalam kehidupan rumah tangga, organisasi kemasyarakatan, bahkan pada saat seseorang memasuki dunia kerja. Seseorang tersebut akan berinteraksi, dan masuk menjadi bagian dalam organisasi tempatnya bekerja Salah satunya adalah upaya dalam peningkatan sumber daya manusia dalam perusahaan atau organisasi. Lembaga keuangan syariah, mendasarkan dirinya pada operasional syariah yang diturunkan dalam ekonomi Islam. Baik itu berbentuk Bank, Koperasi, BMT, maupun berbentuk BPRS. Lembaga Keuangan Syariah sebagai sebuah institusi, ia hidup tumbuh dan berkembang di tengah masyarakat. Semakin maju masyarakatnya diharapkan pula lembaga keuangan syariah dapat mengikuti zaman.

Oleh karena itu lembaga keuangan syariah harus bekerja sama dengan semua kekuatan Islam agar pelaksanaan Islam dalam masyarakat tersebut semakin berkembang. Meskipun kehadiran Lembaga Keuangan Syariah dianggap relatif masih baru di tengah-tengah masyarakatnya, namun banyak orang-orang yang memiliki perhatian terhadap lembaga kecil ini. Di samping itu juga merangkul masyarakat yang bukan pengusaha, yaitu masyarakat-masyarakat kecil yang belum tersentuh oleh perbankan secara umum. Demikian halnya dengan salah satu Lembaga Keuangan Syariah yang beramatkan di Jalan Raya Sreangat, Desa Begelen , Kabupaten Blitar . Bina Artha Ventura merupakan lembaga keuangan yang berbasis syariah, penambahan modal tanpa riba, dengan program pinjaman dengan berkelompok dikhususkan untuk ibu - ibu . Kepemimpinan merupakan tulang punggung pengembangan organisasi . Cara dan pola tingkah laku pemimpin diartikan oleh bawahan yang berkerjasama dengannya sebagai gaya kepemimpinan. Menurut Kartono (2005:153) kepemimpinan adalah kemampuan untuk memberikan pengaruh yang konstruktif kepada orang lain untuk melakukan satu usaha kooperatif mencapai tujuan yang sudah direncanakan. Rivai (2004:2),

Gaya kepemimpinan dan disiplin kerja merupakan bagian dari faktor-faktor yang dapat mempengaruhi kinerja karyawan. Baik buruknya ataupun sesuai tidaknya gaya kepemimpinan yang diterapkan dalam suatu organisasi maka hal tersebut akan 
berpengaruh terhadap kinerja karyawannya. Begitu juga dengan disiplin kerja, tinggi ataupun rendahnya disiplin karyawan pada suatu organisasi tentunya juga berdampak/berpengaruh terhadap kinerja dalam organisasi tersebut.

Dengan mangacu pada rumusan masalah di atas, maka penelitian ini bertujuan untuk mengetahui pengaruh gaya kepemimpinan dan disiplin kerja terhadap kinerja karyawan di Lembaga Keuangan Bina Artha Ventura. Untuk memudahkan pencapaian tujuan utama tersebut, (1) Untuk mengetahui gaya kepemimpinan yang diterapkan oleh Kepala Lembaga Keuangan Bina Artha Ventura, (2) Untuk mengetahui pengaruh gaya kepemimpinan terhadap kinerja karyawan di Lembaga Keuangan Bina Artha Ventura .

\section{Pengertian Kepemimpinan}

Secara umum pengertian kepemimpinan adalah suatu kekuatan yang menggerakkan perjuangan atau kegiatan yang menuju sukses.

Pengertian Kepemimpinan Menurut Para Ahli, antara lain : (a) Wahjosumidjo (1987:11): Pengertian kepemimpinan menurut Wahjosumidjo adalah suatu yang melekat pada diri seorang pemimpin yang berupa sifat-sifat tertentu seperti: kepribadian (personality), kemampuan (ability), dan kesanggupan (capability), kepemimpinan sebagai rangkaian kegiatan (activity) pemimpin yang tidak dapat dipisahkan dengan kedudukan (posisi) serta gaya atau perilaku pemimpin itu sendiri.

\section{Gaya Kepemimpinan}

\section{Pengertian Gaya Kepemimpinan}

Setiap pemimpin pada dasarnya memiliki perilaku yang berbeda dalam memimpin para pengikutnya, perilaku para pemimpin itu disebut dengan gaya kepemimpinan. Gaya kepemimpinan merupakan suatu cara pemimpin untuk mempengaruhi bawahannya yang dinyatakan dalam bentuk pola tingkah laku atau kepribadian.

Menurut Kartini Kartono (2008:34) , “Gaya kepemimpinan adalah sifat, kebiasaan, tempramen, watak dan kepribadian yang membedakan seorang pemimpin dalam berinteraksi dengan orang lain" . Menurut Miftah Thoha (2010:49) mengemukakan bahwa : "Gaya kepemimpinan merupakan norma prilaku yang 
digunakan oleh seseorang pada saat orang tersebut mencoba mempengaruhi prilaku orang lain atau bawahan”. Menurut Yayat M Herujito (2006:188) mengartikan gaya kepemimpinan adalah "Gaya kepemimpinan bukan bakat, oleh karena itu gaya kepemimpinan dipelajari dan dipraktekan dalam penerapannya harus sesuai dengan situasi yang dihadapi”.

\section{Pengertian Kinerja Pegawai}

Setiap pegawai dalam organisasi dituntut untuk memberikan kontribusi positif melalui kinerja yang baik, mengingat kinerja organisasi tergantung pada kinerja pegawainya (Gibson, et all, 1995:364). m kerangka organisasi terdapat hubungan antara kinerja perorangan (individual Performance) dengan kinerja organisasi (Organization Performance). Suatu organisasi pemerintah maupun swasta besar maupun kecil dalam mencapai tujuan yang telah ditetapkan harus melalui kegiatan-kegiatan yang digerakkan oleh orang atau sekelompok orang yang aktif berperan sebagai pelaku, dengan kata lain tercapainya tujuan organisasi hanya dimungkinkan karena adanya upaya yang dilakukan oleh orang dalam organisasi tersebut.

\section{METODOLOGI PENELITIAN}

\section{Desain Penelitian}

Segala prosedur aktivitas penelitian yang peneliti lakukan untuk menyusun penelitian ini, menunjukan bahwa peneliti menggunakan pendekatan kualitatif bersifat deskriptif . Menurut Nazir (1988), metode deskriptif merupakan suatu metode dalam meneliti status sekelompok manusia, suatu objek, suatu set kondisi, suatu sistem pemikiran ataupun suatu kelas peristiwa pada masa sekarang. Tujuan dari penelitian deskriptif ini adalah untuk membuat deskripsi, gambaran, atau lukisan secara sistematis, faktual dan akurat mengenai fakta-fakta, sifat-sifat serta hubungan antarfenomena yang diselidiki.

Menurut Bogdan Dan Taylor dikutip oleh Moleong yang dimaksud penelitian kulitatif adalah “ prosedur penelitian yang menggunakan data deskriptif berupa kata - kata tertulis atau lisan dari orang - orang atau perilaku yang dapat diamati . Menurut Sugiyono (2012:35 ) Penelitian diskriptif adalah penelitian yang dilakukan 
untuk mengetahui nilai variabel mandiri, baik satu variabel atau lebih (independen) tanpa membuat perbandingan, atau menghubungkan dengan variabel yang lain.

Metode jenis penelitian yang digunakan dalam design ini memfokuskan penelitian penulis menggunakan Metode Grounded Theory . Teori yang grounded adalah teori yang diperoleh secara induktif dari penelitian tentang fenomena yang dijelaskan. Pengumpulan data, analisis dan teori saling terkait dalam hubungan timbal balik. Peneliti tidak memulai penyelidikan dengan satu teori tertentu lalu membuktikannya, namun dengan suatu bidang kajian dan hal-hal yang terkait dengan bidang tersebut. Tujuan metode grounded theory adalah menyusun teori yang sesuai dengan dan menjelaskan tentang bidang yang diteliti

\section{Lokasi Penelitian dan Waktu Penelitian}

Penelitian menjadi obyek penelitian sesuai dengan judul penelitianini tepatnya di Kantor Bina Artha Cabang Srengat yang terletak di Jalan Raya Srengat, Kabupaten Blitar. Waktu penelitian dilaksanakan tanggal 15 Mei - 30 Juni 2017 . Beberapa pertimbangan yang mendasari dipilihnya lokasi penelitian tersebut, antara lain :

1. Lokasi tersebut sesuai dengan rencana dan judul penelitian .

2. Berdasarkan hasil pengamatan sementara pada Kantor Bina Artha diperkirakan dapat mewakili tentang permasalahan pokok gaya kepemimpinan terhadap kinerja karyawan .

\section{Instrument Penelitian}

Dalam penelitian kualitatif, yang menjadi instrument atau alat penelitian adalah peneliti itu sendiri sehingga peneliti harus " divalidasi " . Validasi terhadap peneliti meliputi : pemahaman metode penelitian kualitatif , pengukuran wawasan terhadap bidang yang diteliti, kesiapan peneliti untuk memasuki obyek penelitian baik secara akademik maupun logikanya ( Sugiono , 2009 : 305 ). Peneliti kualitatif sebagai human instrumen berfungsi menetapkan fokus penelitian, memilih informan sebagai sumber data, melakukan pengumpulan data, menilai kualitas data, analisis data, menafsirkan data dan membuat kesimpulan atas temuannya 
(Sugiono,2009:306). Sehingga focus penelitian kami pada instrument variable sehingga sebagai berikut :

1. Gaya kepemimpinan

2. Kinerja Karyawan

\section{HASIL DAN PEMBAHASAN}

\section{Hasil}

PT Bina Artha Ventura didirikan pada tahun 2011 dan merupakan institusi keuangan non-bank yang beroperasi di sektor keuangan mikro untuk memberikan dana modal kepada masyarakat level ekonomi lemah. PT Bina Artha Ventura menawarkan pelayanan pemberian modal kerja yang merupakan bentuk modern dari metodologi microfinance tradisional. Berdasarkan data tahun 2015, Bina Artha memiliki sekitar 154 cabang dan melayani 164.176 mitra di Indonesia. PT. Bina Artha Ventura adalah Modal Ventura Perusahaan terdaftar aktif terlibat dalam sektor keuangan mikro yang menerima lisensi untuk beroperasi oleh Bapepam-LK (Departemen Keuangan) pada bulan November 2011 dan mulai beroperasi pada Desember 2011. Nama "Bina Artha" adalah istilah bahasa Indonesia yang dapat diterjemahkan menjadi "Modal untuk Pengembangan".

Bina Artha menawarkan modal kerja melalui versi modifikasi dari metodologi keuangan mikro Grameen tradisional kelompok secara eksklusif untuk wanita yang tidak memiliki atau hanya memiliki akses parsial ke sektor keuangan formal. Kami di Bina Artha terinspirasi dari ideal yang availing akses keuangan bagi rumah tangga kurang terlibat dalam usaha mikro dan kecil di Jawa memberikan mereka alat penting untuk mencapai upliftment ekonomi dan sosial.

Dalam jawa timur saja ada kurang lebih 100 kantor cabang yang tersebar . Salah satunya cabang yang berada di Kota Blitar yaitu Kantor Cabang Srengat ini . Cabang Srengat sudah berdiri sejak tahun 2014 bulan agustus hingga saat ini kurang lebih sudah tiga tahun . Cabang Srengat merupakan cabang kedua di yang didirikan setelah Cabang Talun . Cabang Srengat masuk dalam Area 4 Regional 2 . Cabang 
Srengat sudah memiliki kurang lebih 1321 Mitra per bulan agustus . Dengan target minimum sampai 1600 mitra dalam satu tahun ini .

Tabel 1. Daftar Kantor Cabang Area 4 Regional 2

\begin{tabular}{|r|l|l|}
\hline No & Nama Cabang & Kode Cabang \\
\hline 1. & Kantor Cabang Talun & 0089 \\
\hline 2. & Kantor Cabang Srengat & 0091 \\
\hline 3. & Kantor Cabang Boyolangu & 0094 \\
\hline 4. & Kantor Cabang Ngunut & 0095 \\
\hline 5. & Kantor Cabang Durenan & 0107 \\
\hline
\end{tabular}

Sumber : Data Sekunder Kantor Bina Artha

\section{Visi, Misi Dan Tujuan}

Visi :

“ Menjadi lembaga keuangan khusus yang terkemuka dengan melayani 1.000.000 keluarga di Indonesia di tahun 2020.

Misi :

“ Meneyediakan keuangan khusus untuk masyarakat berpendapatan rendah yang aktif dalam kegiatan perekonimian dengan memperhatikan aspek kewajaran dan kelayakan, transparasi, evisiensi serta berkelanjutan .

\section{Tujuan :}

1. Membantu serta memberi kesempatan kepada masyarakat berpendapatan rendah , khusunya perempuan dalam upaya mendapatkan modal kerja untuk membangun atau menegembangkan usahanya .

2. Memanfaatkan waktu dan kemampuan perempuan agar dapat berkontribusi dalam memenuhi kebutuhan dan meningkatkan kesehjahteraan keluarganya .

Tugas Pokok Karyawan Bina Artha 


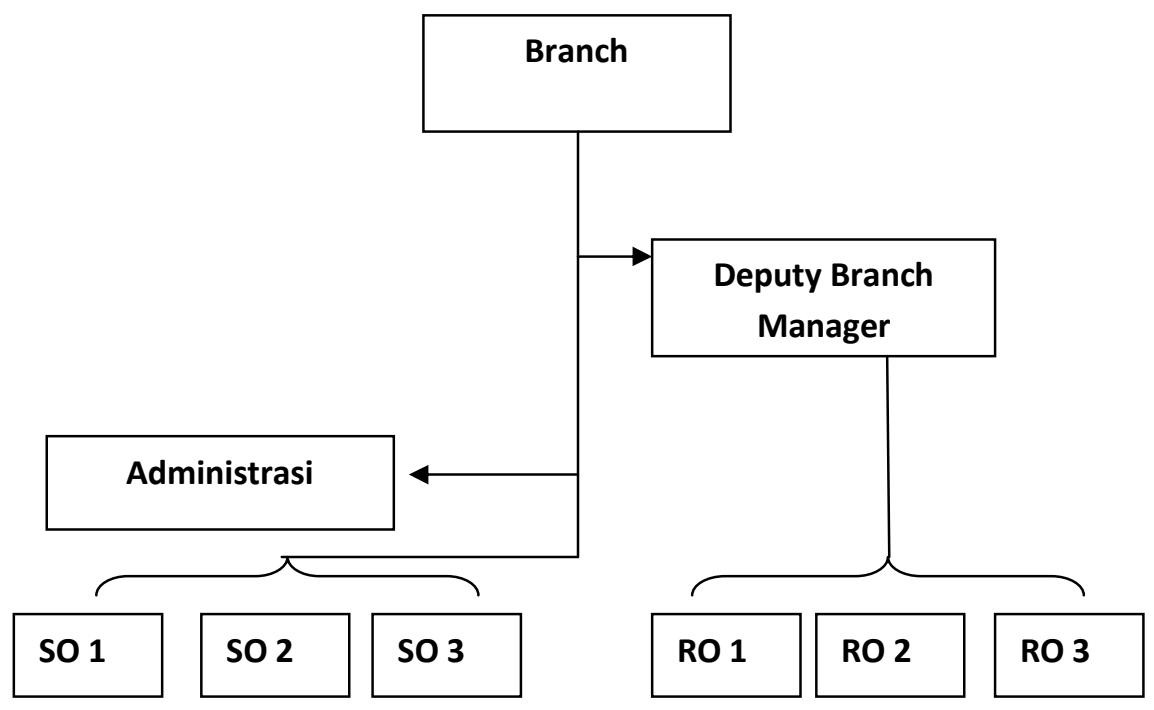

Gambar 1. Struktur Organisasi Kantor Bina Artha Cabang Srengat

Sumber : Data Sekunder Kantor Bina Artha

\section{Karakteristik Responden}

Di bagian ini menjelaskan gambaran umum tentang responden yang terdiri dari pegawai Kantor Bina Artha Cabang Srengat . Total keseluruhan untuk pegawai yang diteliti adalah 7 Orang. Dalam penelitian ini karakteristik responden dianalisis secara deskriptif dan peubah yang dianalisis meliputi Jenis Kelamin, Umur , Pendidikan Terakhir .

\section{Pembahasan}

\section{Gaya Kepemimpinan}

Dalam wawanacara bebeberapa waktu lalu tentang gaya kepemimpinan disampaikan kepada pegawai yang terdiri dari sales officer, relation officer, administrasi untuk mengetahui gaya kepemimpinan yang memengaruhi kinerja pegawai. Gaya kepemimpinan seseorang adalah tingkah laku yang dilakukan oleh seorang pemimpin dalam proses mengarahkan dan memengaruhi orang-orang di bawahnya. Gaya kepemimpinan adalah suatu cara, atau teknik seseorang dalam menjalankan suatu kepemimpinan dan dapat pula diartikan sebagai norma perilaku 
yang digunakan seseorang pada saat orang tersebut mencoba mempengaruhi orang lain seperti yang dilihat. Menurut hasil wawancara terhadap gaya kepemimpinan di Kantor Bina Artha Cabang Srengat, sebagian berikut pendapat karyawan antara lain

a. Mempimpin dengan cara kekeluargaan, demokrasi . Jadi menampung aspirasi - aspirasi dari setiap karyawan jadi di musyawarahkan .

b. Tegas dan selalu bisa membimbing anak buahnya senantiasa untuk memajukan cabang srengat .

c. Memberikan contoh ke bawahannya, bahwa kepala cabang yang mau turun ke lapangan .

d. Menyelaraskan kepentingan tim daripada kepentingan pribadi, karena setiap belum tugas selesai atau tuntas waktu pulang selalu di undur .

e. Secara banyak pengaruh kepemimpinannya , artinya beliau punya kebijakan kepada karyawan , kebijakan tertentu untuk setiap karyawannya

f. Tidak ada batasan antara bos dengan karyawan karena Bu Meyta selalu menanamkan jiwa kekeluargaan .

Selain itu Kepala Kantor Bina Artha Cabang Srengat memiliki program baru , yaitu koin telat dimulai bulan Juni . Koin telat ini merupakan program , jam masuk kantor itu 08.00 apabila salah satu karyawan telat datang kantor dengan aturan per 30 menit mlaumpaui jam 08.00 akan membayar sebesar Rp.2500 , dan utuk kepala cabang sendiri dendanya $2 \mathrm{X}$ lipat dari karyawan. Hal ini digunkana untuk mengingkatkan tingkat kedisiplinan karyawan dan sudah banyak perubahan dari karyawan . Hal ini menggambarkan bahwa Kepala Kantor Bina Artha Cabang Srengat ini di buktikan dari hasil wawancara diatas bahwa gaya kepemimpinan yang diterapkan yaitu Gaya Kepemimpinan Demokratis .

\section{Kinerja Karyawan Bina Artha Cabang Srengat}

\section{Kualitas Kerja}

Kualitas Kerja ditentukan dari teknologi, sistem kerja , cara kerja , dan intregritas pribadi masing - masing . Kualitas kerja ini berbeda - beda setiap karyawan . Sumber daya manusia dan intregritas individu berfokus pada kualitas kerja . Dalam kualitas kerja sangat diharapkan kemajuan serta perkembangan 
organisasi memelalui peningkatan kinerja . Di Bina Artha cabang srengat sertiap karyawan memiliki produk kerja yang akan dihasilkan kulalitas kerja berikut ini, antara lain :

a. Relation Officer

Produk kerja yang dihasilkan mengambil angsuran mitra - mitra dari angsuran diharapkan setiap harinya tidak ada mitra yang melakukan PAR . PAR merupakan istilah tunggakan bagi mitra, petugas harus bisa menekan angka PAR untuk turun atau menekan tidak terjadinya PAR . Karena keberhasilkan kantor bisa dikatan target salah satunya tingkat PAR itu bisa turun . Bisa dilihat dari table PAR 5 bulan terakhir .

\section{Tabel 2. Daftar PAR}

\begin{tabular}{|r|l|l|}
\hline NO & BULAN & JUMLAH PAR \\
\hline 1. & MARET & 421.000 .000 \\
\hline 2. & APRIL & 320.000 .000 \\
\hline 3. & MEI & 270.000 .000 \\
\hline 4. & JUNI & 220.000 .000 \\
\hline 5. & JULY & 190.000 .0000 \\
\hline
\end{tabular}

Sumber : Data Sekunder Kantor Bina Artha Cabang Srengat

Dapat dilihat bahwa setiap bulannya dimulai dari bulan maret hingga juni jumlah PAR di kantor cabang srengat mengalami kecenderungan progress yang sangat baik, karena perusahaan mewajibkan setiap bulannya menurunkan PAR dan meminimalisir jumlah PAR tidak bertambah lagi . Jadi bisa dikatan kualitas kerja bagian RO sangatlah baik .

b. Sales Officer

Produk kerja yang dihasilkan yaitu untuk pencarian nasabah untuk menjadi mitra baru . Karena perusahaan mewajibkan mengirimkan mitra baru 100 mitra baru per bulannya . Bisa dilihat dari hasil mitra baru 5 bulan terakhir, yaitu : 
Tabel 3. Daftar Jumlah Mitra

\begin{tabular}{|c|l|l|}
\hline NO & NAMA BULAN & JUMLAH MITRA BARU \\
\hline 1. & MARET & 115 Mitra \\
\hline 2. & APRIL & 125 Mitra \\
\hline 3. & MEI & 100 Mitra \\
\hline 4. & JUNI & 121 Mitra \\
\hline 5. & JULY & 116 Mitra \\
\hline
\end{tabular}

Sumber : Data Sekunder Kantor Bina Artha Cabang Srengat

Dapat dilihat bahwa jumlah mitra mulai bulan maret sampai bulan juli mengalami peningkatan target yang dibuat langsung oleh CEO Bina Artha Bapak Agung Merangga . Diturunkan ke masing - masing region manager disampaikan oleh Bapak I Made Antara dan disampaikan kepada cabang di regional masing masing . Proses diatas merupakan proses data mitra baru yang masuk diperusahaan dan di acc oleh perusahaan. Maka dari itu Bina Artha cabang srengat memperoleh target . Sampai bulan july jumlah mitra mencapai 1246 Mitra , Sedangkan target dari perusahaan sampai tutup tahun 2017 harus mencapai 1700 mitra . Karena idealnya setiap cabang harus memiliki mitra 1700 apabila mitra sudah terpenuhi, petugas tidak perlu lagi mencari mitra akan tetapi bagaimana petugas mempertahankan mitra0 8a salah satu cabang tidak target perusahaann akan memberikan sanksi berupa lembar coaching atau peringatan . Untuk peraturan per area berbeda - beda . Untuk Regional 2 Area 4 memiliki peraturan bagi cabang target akan mendapatkan bonus 1 juta dari perusahaan, dan apabila cabang tidak target akan membayarkan denda sebesar 200 ribu .

\section{Administrasi}

Untuk bagian administrasi produk kerja yang paling inti apa yang dibutuhkan oleh Sales Officer dan Relation Officer baik secara administrasi dan non administrasi guna mendukung perkejaanya .Selain tugas - tugas lainnya . Salah satu faktor lain yang kantor target adalah tugas bagian administrasi . 
Dari hasil diatas bisa dilihat bagaimana kualitas kerja di kantor Bina Artha Cabang Srengat sangat ada perkembangan, peningkatan kemajuan yang sangat pesat . Hal tersebut tidak lepasnya dari kerjasama tim . Karena keberhasilan tersebut bukan semata dalam satu pihak saja .

\section{Ketepatan Waktu}

Ketepatan waktu merupakan hal yang sangat berharga karena berhubungan dengan waktu tentunya dengan pekerjaanya. Dalam penyelesaian pekerjaan karyawan - karyawan itu memiliki target waktu sendiri - sendiri, sebagian berikut merupakan target waktu untuk setiap bagian - bagian, antara lain :

Tabel 4. Target Yang Harus Dicapai

\begin{tabular}{|r|l|l|}
\hline NO & NAMA BAGIAN & TARGET YANG HARUS DICAPAI \\
\hline 1. & Sales Officer & $\begin{array}{l}\text { Harus menyelesaian pencarian mitra dalam satu } \\
\text { bulannya tidak boleh melaumpaui batas yang } \\
\text { ditentukan satu bulan itu . }\end{array}$ \\
\hline 2. & Relation Officer & $\begin{array}{l}\text { Harus menyelesaian penagihan dalam satu hari } \\
\text { sekitar 5 - 6 kumpulan mitra . Dalam satu mitra } \\
\text { terdiri } 10-20 \text { orang . Dan harus selesai dalam } \\
\text { satu hari , karena setiap harinya sudah diberikan } \\
\text { jadwal yang berbeda - beda setiap harinya . }\end{array}$ \\
\hline 3. & Administrasi & $\begin{array}{l}\text { Harus menyiapkan form - form yang digunakan } \\
\text { untuk keperluan aktivitas pekerjaan di Kantor } \\
\text { Bina Artha Cabang Srengat }\end{array}$ \\
\hline
\end{tabular}

Sumber data : Primer dari Peneliti

Bisa dilihat hasil target diatas sesuai dengan waktu yang telah ditentukan karena salama ini di Kantor Bina Artha selalu berjalan dengan semestinya , karena setiap pekerjaan tersebut ini saling berkesinambungan . 


\section{Inisiatif}

Inisiatif ini muncul dari diri sendiri masing - masing individu . Karena tugas bawahan harus tidak tergantung oleh atasan. Bu Meyta selaku Branch Manager Kantor Bina Artha Cabang Srengat sangat membuka peluang untuk karyawan melalukan penanganan masalah di lapangan dengan sendiri . Jadi di tuntut setiap karyawan harus bisa melakukan penyelesaian problem - problem lapangan . Selain itu keberhasilan kantor target adalah salah satu inisiatif yang dilakukan karyawan . Salah satu contoh melakukan hubungan baik dengan mitra tanpa mengurangi batasan antara petugas dengan mitra itu merupakan inisiatif yang bisa dilakukan .

\section{Kemampuan}

Menjalankan tugas dan tanggung jawab tidak lepas dari bagaimana petugas menjalankannya . Bisa dilihat bagaimana kinerja petugas, hal itu tidak lepas dari faktir kemampuan. Untuk hal itu sebelum berkerja di Kantor Bina Artha setiap karyawan selalu mendapatkan diklat pra kerja dan training. Selain itu ada proses seleksi sebelum masuk kerja. Dalam pembekalan sebelum kerja, karyawan diharapkan paham dan dapat bisa berkerja dengan baik . Mengetahui hal apa yang harus dilakukan sesuai dengan bagian masing - masing .

\section{Tabel 5. Waktu Pembekalan Pra Kerja Di Kantor Bina Artha}

\begin{tabular}{|c|l|l|}
\hline NO & NAMA BAGIAN & WAKTU \\
\hline 1. & Sales Officer & 2 Minggu \\
\hline 2. & Relation Officer & 2 Minggu \\
\hline 3. & Administrasi & 3 Minggu \\
\hline
\end{tabular}

Sumber : Data Primer dari Peneliti

\section{Komunikasi}

Komunkasi adalah salah satu bentuk apresiasi terbesar dalam sebuah hubungan. Dimana ketika komunikasi terjalin dengan baik akan memberikan feedback yang baik pula. Komunikasi di tempat kerja dapat terbagi menjadi beberapa bentuk, berdasar dari hal ini menentukan komunikasi dalam bentuk apa yang akan 
Anda wujudkan baik terhadap atasan ataupun rekan kerja. Dalam komunikasi salama terjadinya miss komunikasi merupakan hal sangat wajar tapi bagaimana antar karyawan melakukan hal yang membuat minimal . Dalam komunikasi sehari - hari setiap karyawan memiliki cara sendiri - sendiri dalam kegiatan sehari - hari . Dalam praktek lapangan setiap karyawan menggunakan bahasa daerah setempat atau menggunakan Bahasa Indonesia tergantung melihat dengan siapa lawan bicara mereka . Seringnya menggunakan bahasa daerah dalam pekerjaan .

\section{Analisi Gaya Kepemimpinan Terhadap Kinerja}

Bahwa gaya kepemimpinan Kepala Kantor Bina Artha Cabang Srengat berpengaruh terhadap kinerja karyawan. Disamping itu juga sifat kekeluargaan , selalu memberikan dukungan, motivasi untuk menunjang pekerjaan karyawan . Hal tersebut dapat dilihat dari analisis data dengan metode wawancara dengan beberapa sub pertanyakan, hasil menunjukkan progress dari setiap bagian - bagian mengalami target, antara lain tingkat angka PAR setiap bulannya menurun karena tingkat angka PAR harus bisa diturunkan dan jumlah mitra baru setiap bulannya bertambah sesuai dengan target yang di wajibkan oleh pihak kantor minimal 100 mitra .

\section{PENUTUP}

\section{Kesimpulan}

Kesimpulannya adalah: (1) Kepemimpinan demokratis merupakan gaya kepemimpinan yang diterapkan di Kantor Bina Artha Cabang Srengat berupaya Berusaha menyelaraskan kepentingan dan tujuan pribadi dengan kepentingan organisasi, Senang menerima saran, pendapat dan kritik dari bawahannya, Mentorelir bawahan yang membuat kesalahan dengan memberikanpendidikan kepada bawahan untuk tidak mengulangi kesalahan, Lebih menitikberatkan kerjasama dalam mencapai tujuan . Selain itu semua terselip sebuah program yaitu koin telat dimulai bulan Juni . Koin telat ini merupakan program , jam masuk kantor itu 08.00 apabila salah satu karyawan telat datang kantor dengan aturan per 30 menit 
mlaumpaui jam 08.00 akan membayar sebesar Rp.2500, dan utuk kepala cabang sendiri dendanya 2 X lipat dari karyawan . Hal ini digunkana untuk mengingkatkan tingkat kedisiplinan karyawan dan sudah banyak perubahan dari karyawan , (2) Kinerja karyawan Kantor Bina Artha Cabang Srengat, ini bisa dilihat dari tingkat angka PAR dalam 5 bulan terakhir yang turun di mulai bulan maret dari angka Rp. 420.000.000 sampai bulan july masuk di angka Rp.190.000.000 mengalami penurunan angkanya dan menekan untuk tidak bertambah lagi . Mitra baru yang masuk dikantor per bulannya yang mengalami penambahan mitra dan selalu target . Dari hasil diatas bisa dilihat kinerja karyawan baik dan selalu memiliki progress yang baik

\section{Saran}

Saran: (1) Gaya Kepemimpinan yang demokrasi sangatlah cocok untuk era sekarang karena kerja sama tim juga merupakan factor pendukungnya . Sangat berdampak untuk Kantor Bina Artha Cabang Srengat Menjadi lebih baik lagi, (2) Untuk mempertahankan dan meningkatkan kinerja pegawai sesuai kriteria kinerja yang telah diterapkan, selalu melakukan inovasi - inovasi untuk menyesuaikan dengan problem dilapangan juga selain itu factor perkembangan teknologi, (3) Agar gaya kepemimpinan di Kantor Bina Artha Cabang Srengat berdampak positif bagi peningkatan kinerja pegawai, maka kepemimpinan kepala Kantor Bina Artha Cabang Srengat perlu diberdayakan. Pemberdayaan kepala mengandung arti peningkatan kemampuan secara fungsional, dimana kepala sekolah mampu berperan sesuai dengan tugas, fungsi, wewenang dan tanggungjawabnya, baik itu sebagai pemimpin bagi karyawan. Hal ini dikarenakan, tugas dan fungsi kepala sekolah merupakan sosok sentral dalam peningkatan kualitas kerja pegawai 


\section{DAFTAR PUSTAKA}

Bungin, Burhan.2004. Penelitian Kualitatif. Jakarta: Gramedia.

Dessler Gary. 2005. Manajemen sumberdaya manusia jilid 2. Jakarta: Gramedia

Dharma, Surya. 2010. Manajemen Kinerja.Yogyakarta: PustakaPelajar.

Herdiansyah,Haris. 2010. Metodologi Penelitian Kualitatif untuk Ilmu Sosial. Jakarta: Salemba Humanika.

Hermansyah, H. 2009. Metode Penelitian Kualitatif, Seni dalam Memahami Fenomena Social. Yogyakarta: Greentea Publishing.

Kartono, Kartini.2009. Pengantar Metodologi Riset Sosial. Bandung: Mandar Maju

Lako, Andreas, 2004. Kepemimpinan dan Kinerja Organisasi :Isu, Teori dan Solusi. Jakarta: Gramedia.

Mangkunegara.2005, Evaluasi Kinerja Sumber Daya Manusia. Jakarta: Gramedia

Milles, Mattew B., dan A. Michael Huberman. 2007. Analisis Data Kualitatif. Jakarta: Gramedia

Moleong, Lexy J. 2002. Metodologi Penelitian Kualitatif. Bandung : PT Remaja Rosdakarya.

Regina Aditya Reza, Pengaruh Gaya Kepemimpinan, Motivasi dan Disiplin Kerja Terhadap Kinerja Karyawan PT. SinarSentosa Perkasa Banjarnegara, (Semarang: Skripsi TidakDiterbitkan, 2010).

Robbins, Stephen P. 2001. Perilaku Organisasi. Jakarta: PT. Prenhallindo. 